\title{
COASTAL GEOMORPHOSITES ASSESSMENT FOR ECOTOURISM DEVELOPMENT IN EAST LOMBOK, INDONESIA
}

\author{
Danang Sri HADMOKO \\ Universitas Gadjah Mada, Faculty of Geography, Environmental Geography Department, Yogyakarta, Indonesia, e-mail: hadmoko@ugm.ac.id \\ Muh Aris MARFAI* \\ Universitas Gadjah Mada, Faculty of Geography, Environmental Geography Department, Yogyakarta, Indonesia, e-mail: arismarfai@ugm.ac.id \\ Mukhamad Ngainul MALAWANI \\ Universitas Gadjah Mada, Faculty of Geography, Environmental Geography Department, Yogyakarta, Indonesia, e-mail: malawani@ugm.ac.id
}

\author{
Bachtiar Wahyu MUTAQIN
}

Universitas Gadjah Mada, Faculty of Geography, Environmental Geography Department, Yogyakarta, Indonesia, e-mail: mutaqin@ugm.ac.id

\section{Anindya Arma RISANTI}

Universitas Gadjah Mada, Faculty of Geography, Master Program on Planning and management of Coastal Area and Watershed, D.I. Yogyakarta, Indonesia, e-mail: anindya.arma.r@mail.ugm.c.id

Astry Zulky PERMATASARI

Universitas Gadjah Mada, Faculty of Geography, Environmental Geography Department, Yogyakarta, Indonesia, e-mail: astry.z@mail.ugm.ac.id

\begin{abstract}
Citation: Hadmoko, D.S., Marfai, M.A., Malawani, M.N., Mutaqin, B.W., Risanti, A.A., \& Permatasari, A.Z. (2021). COASTAL GEOMORPHOSITES ASSESSMENT FOR ECOTOURISM DEVELOPMENT IN EAST LOMBOK, INDONESIA. GeoJournal of Tourism and Geosites, 36(2spl), 589-596. https://doi.org/10.30892/gtg.362spl05-687
\end{abstract}

\begin{abstract}
The research set out to analyze coastal typology characteristics and ecotourism development through geomorphosite assessments and suggest fitting management strategies in East Lombok, Indonesia. In this research, the connection between ecotourism potentials and coastal typologies was investigated. The methods of this research were conducted using a combination of GIS-based analysis and field surveys. Geomorphosites were assessed from several facets or attributes: scientific and intrinsic, educational, economic, conservation, and added values. The analysis results showed that two coastal geomorphosites could be developed into ecotourism spots, as supported by East Lombok's regional planning to promote ecotourism in its tourism branding. In addition, the sites are suggested to develop local products as a part of their attractiveness. Another finding is that the coastal typology has a strong connection to the scoring result, especially the scientific-intrinsic and conservation values.
\end{abstract}

Key words: coastal typology, geomorphosite, ecotourism, East Lombok, Indonesia

\section{INTRODUCTION}

Tourism is one of the leading sectors in Indonesia's development. It is known and, thus, expected to increase foreign exchange earnings, regional income and growth, investment, and labour markets. In addition, tourism also contributes to Indonesia's account balance (Narayan et al., 2021). Indonesia has enormous natural resource potentials and rich biodiversity to trigger and accommodate tourism development, yet this process remains less than optimum due to the lack of supporting facilities and infrastructures (Nandi, 2008; Badarab et al., 2017; Marfai et al., 2020). Among the diverse tourism potentials targeted for development is coastal-marine tourism. Bali Island is a famous global destination for cultural and coastal-marine tourism (Marfai et al., 2020; Mutaqin et al., 2020). Its popularity has begun to spread to neighboring islands, one of which is Lombok. Lombok also offers coastal tourism in, among others, Senggigi and Gili Trawangan (West Lombok) and integrated coastal tourism in Kuta-Mandalika (Central Lombok) that has just been recently developed. On the contrary, East Lombok, which is no less attractive than the areas mentioned above, remains untouched by development plans and, as such, improperly managed. In West Nusa Tenggara Regional Tourism Development Master Plan (RIPARDA: Rencana Induk Pembangunan Kepariwisataan Daerah) for 2013-2028, Lombok Island has four Regional Tourism Strategic Areas prioritized in tourism development. However, plans for more than half of the eastern coastal stretch are still lacking (Figure 1) as they only include Mount Rinjani and Sembalun for mountaineering tourism. Meanwhile, the coastal areas that are mostly developed are located on the west side (Statistics, 2019). This study focuses on East Lombok's coastal area because its tourism sector generates relatively low regional income and does not entirely adopt the ecotourism concept. Recently, the ecotourism concept has developed in several sites in Lombok by the collaborations between governments, private sectors, and communities. 


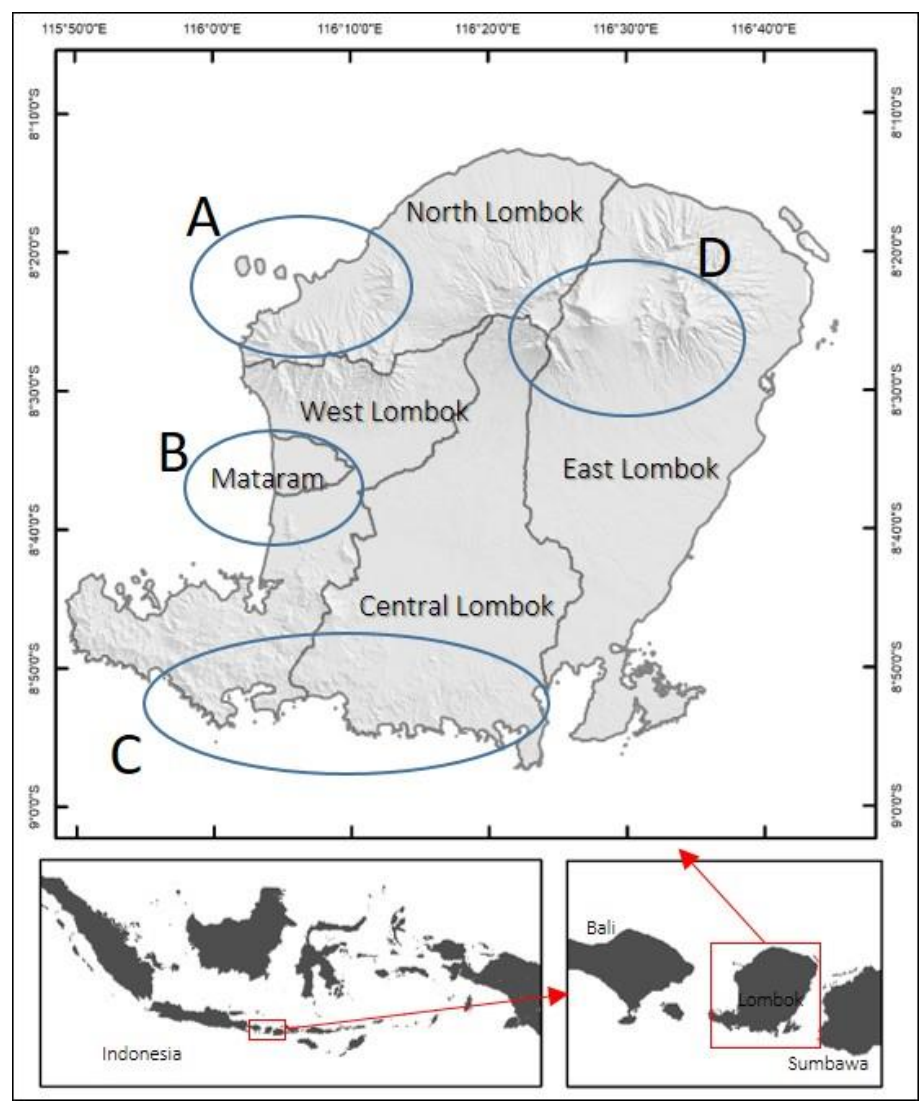

Figure 1. Four regional tourism strategic areas on Lombok Island based on RIPARDA: (A) Senggigi-Gili and (C) Kuta-Mandalika area for coastal tourism, (B) Mataram area for urban tourism, and (D) Rinjani Sembalun area for mountain tourism
The ecotourism concept has five aspects: naturebased, ecologically sustainable, environmentally educative, locally beneficial, and providing tourists with a satisfying experience (Hill and Gale, 2009). Ecotourism can positively impact local community development and environment conservation (Buckley, 2003; Tanaya and Rudiarto, 2014; Pattiwael, 2018). It is also enhancing children's education and improving local people's capabilities in management and other related areas (Masud et al., 2017; Zacarias and Loyola, 2017). Several tourism sites in central and western Lombok have adopted it. However, the tourism potentials of only particular coastal areas are known, while that of many others has yet to be explored due to the missing knowledge of their attractiveness and proper strategies for their development as coastal-marine tourist attractions (Khoiriyah et al., 2018). Geological settings are a known factor of coastal area formation. Lombok is composed of old and young volcanic materials, uplifted limestones, intrusive rocks, and coral reef formations (Mangga et al., 1994; Mutaqin, 2020), and as a result, it has various coastal typologies. For ecotourism development purposes in coastal areas, it is necessary to consider geological and geomorphological aspects (Newsome and Dowling, 2006) in addition to hydrodynamics, geodynamics, morphodynamics, eco-dynamics, and anthropo-dynamics typical of these areas (Sunarto et al., 2014). The dynamics of coastal geomorphological processes, notably in East Lombok and their relation to ecotourism are under-researched. Studies concerning this issue are limited: e.g. the identification of coastal materials, sea current, and wave typology of Tangsi Beach (Rayadi, 2016; Marfai et al., 2019) and coral reef profile (Mutaqin, 2020). This study relies on geomorphosite assessment as an approach to determine ecotourism development potentials in East Lombok. Geomorphosites are geomorphological landforms to which socio-economic, cultural, and/or scientific values are attributed (Panizza, 2001), and in many relevant studies, ecological and aesthetic values are added as known attributes for geomorphosites (Reynard and Panizza, 2005). These attributes create a powerful approach to assess the positive relationship between physical environments and social characteristics, components of ecotourism development (Kubalíková, 2013). In some specific cases, the assessments also beneficial for supporting the development of geopark (Kubalíková, 2019), coastal protection (Pereira et al., 2019), and geoconservation (Santos et al., 2020). For the first time in East Lombok's coastal area, the ecotourism development potential is linked to coastal typologies, which significantly shape the local physical characteristics. This is a further development from previous studies that have correlated geomorphosites with geomorphic genesis, e.g., dissolution (De Waele et al., 2005), marine processes (Orrù et al., 2005), and volcanic landform (Costa, 2011; Quesada-Román et al., 2020). This study was intended to analyze coastal typology and ecotourism development through geomorphosite assessments and provide recommendations on management strategies.

\section{MATERIALS AND METHODS}

The research started with geological and geomorphological feature identification and determination of sampling sites using GIS (Geographic Information System) in the laboratory. The data analyzed were the geological map of Lombok Island (1:100,000) (Mangga et al., 1994), Indonesia Topographic Map (RBI 1:25,000), and DEMNAS (0.27 arcsecond). DEMNAS, available at http://tides.big.go.id/DEMNAS/, is the national digital elevation model in Indonesia and is suitable for landform identification, especially in a volcanic landscape and its surroundings (Malawani et al., 2020a). Using the three data above, this research identified and characterized coastal typology according to Shepard's coastal classification system (1973). It also sought for any coastal tourism sites using the search engine in Google Map (Figure 2). The second step was field surveys to confirm the current and potential coastal tourism sites identified through the GIS-based analysis. One sampling site was removed from the research because of accessibility reasons, thus leaving seven samples (Figure 3). Also, during the field surveys, each sample's geomorphological characteristics were measured and determined using several variables: material constituent, slope, wave breaker type, sedimentation-erosion process, and beach type, and the coastal typologies-determined using Shepard's coastal classification system (1973)—-were validated. The next step was the geomorphosite assessment using the data collected through direct observation and interviews. Several actors related to tourism management in each sampling site (e.g., tourist operators, villagers, and tourists) were interviewed. There are plenty of methods for geomorphosite assessment. Mucivuna et al. (2019) have been listed 71 methods of assessment, one of them is from Kubalíková (2013) which contain several geomorphosite attributes: scientific and intrinsic value, educational value, economic value, conservation value, and added value. The method from 
Kubalíková (2013) was chosen because it suits ecotourism development purposes. This method also combined qualitative and quantitative evaluation (Mucivuna et al., 2019). The final step was scoring, which classified the geomorphosite's readiness for ecotourism development. It was also conducted a comparative analysis between geomorphosite attributes, coastal typology, and the latest issues to suggest the proper management for ecotourism in the sampling sites.

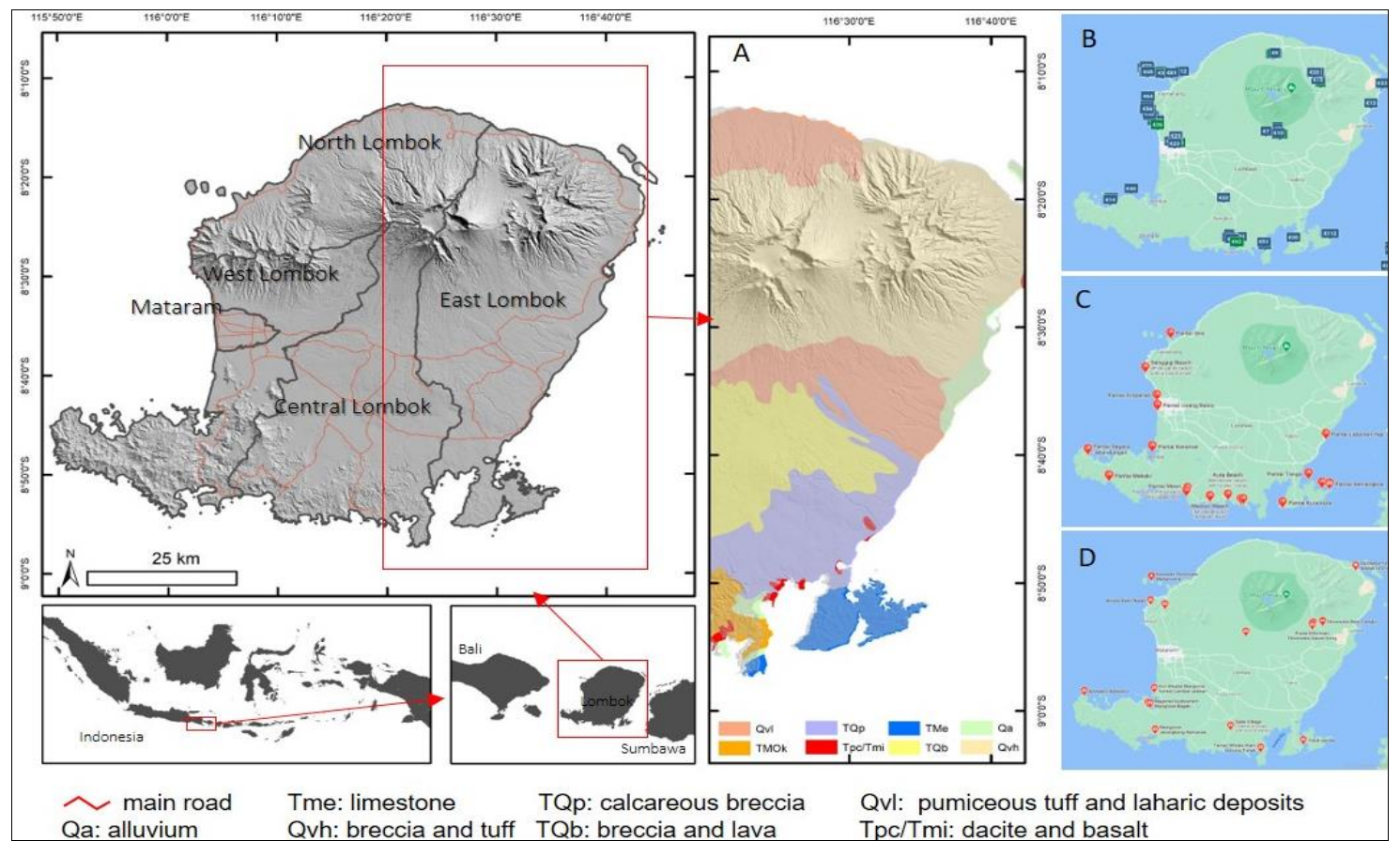

Figure 2. Map of Lombok Island: Geological map of eastern Lombok (A) and Suggested tourism facilities according to the Google Map application: hotels (B), beaches (C), and existing ecotourism sites (D)

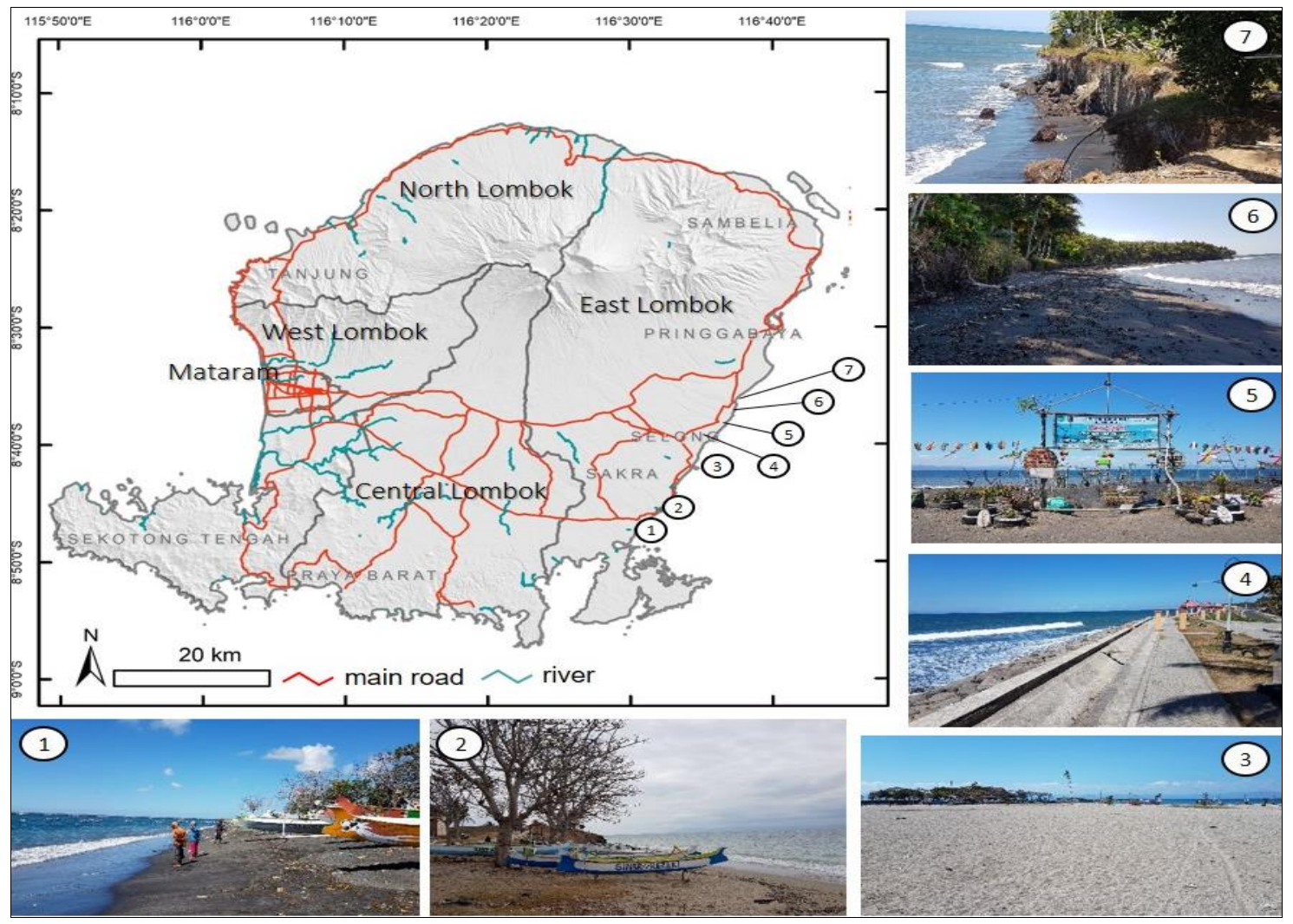

Figure 3. The views of (1) Tanjung Luar, (2) Kwang Wai, (3) Labuhan Haji, (4) Surya Wangi,

(5) Maiq Anyir, (6) Bangsal Korleko, and (7) Gege Korleko Beach (Photo source: field survey, 2020)

\section{RESULTS AND DISCUSSION}

Coastal Typology

The coastal typology characterization was conducted in seven sampling sites (i.e., Kwang Wai, Tanjung Luar, Labuhan 
Haji, Surya Wangi, Maiq Anyir, Gege Korleko, dan Bangsal Korleko Beach) by identifying five variables: beach type, beach material, morphodynamic, slope, and wave breaker type (Figure 3). The samples had various beach types: rocky beach, sandy beach, cliff beach, sandy-rocky-cliff beach, sandy-anthropogenic beach, and anthropogenic beach. The rocky beach in Kwang Wai is formed of andesitic rocks originating in volcanic deposits. Tanjung Luar and Maiq Anyir are mainly composed of sandsized grains; hence, categorized as sandy beaches. Gege Korleko and Bangsal Korleko are cliff beaches, but the latter also have rocky materials. Anthropogenic interferences like concrete structures and sedimentary infills also occur in Labuhan Haji and Surya Wangi. Based on the material analysis, sands were dominant in all sampling sites. Materials deposited in Kwang Wai are breccia, conglomerate, and sand, indicating a strong influence of volcanic activities, as a result of debris-avalanche deposit (Malawani et al., 2020b). Similarly, volcanic processes contribute to the mix of pyroclastic materials deposited in cliff beaches in Gege Korleko and Bangsal Korleko, with another material, i.e., ignimbrite. The combination of fluvial and marine processes in Tanjung Luar and Maiq Anyir allows the deposition of a slightly similar type of sediment, namely sands.

In addition to the widely distributed sands, Tanjung Luar has a marsh area emerging in the west. Meanwhile, the anthropogenic beaches (Labuhan Haji and Surya Wangi) are dominated by sandy materials and paving blocks, particularly along the center of tourism development. The morphodynamic processes were identified to determine which of the sedimentation and erosion was dominant. Kwang Wai, Maiq Anyir, Gege Korleko, and Bangsal Korleko are mainly formed of erosion processes apparent from serious shoreline retreats that reached up to several meters in the last decade, especially in Gege Korleko and Bangsal Korleko. Tanjung Luar and Surya Wangi are mostly influenced by sedimentation processes, as indicated by elongated accumulations of sediment inputs called spits. Spit is a coastal landform that extends to open water, formed by deposition or embankment of sediment in the estuary, which can result in a morphological shifting of the river mouth (Hegde et al., 2012; Zhang, 2016). Spit at Tanjung Luar is longer than the one found at Surya Wangi. Signs of anthropogenic interference are predominant in Surya Wangi, but natural processes still influence its form, although on a small scale.

The research found all three main types of breakers: plunging, spilling, and surging, which are known to vary according to coastal slopes. The breakers in Kwang Wai, Surya Wangi, and Maiq Anyir are plunging. Tanjung Luar dan Labuhan Haji have spilling breakers, while Gege Korleko and Bangsal Korleko had surging breakers. It is indicated that they have a different slope in the surf zone. Based on the characteristics above, East Lombok has five coastal typologies (Table 1). First, the volcanic coast-avalanche beach in the Kwang Wai area is affected by volcanic debris avalanche (DAD) processes. This DAD is connected to the Kalibabak DAD formation, formed prior to the Samalas caldera-forming eruption in 1257 CE (Malawani et al., 2020b). Second, the volcanic coast-pyroclastic surge in Gege Korloko and Bangsal Korleko is composed of deposits of pyroclastic surges, i.e., ash, pumice, and rock fragments ejected during the Samalas eruption in 1257 CE (Lavigne et al., 2013; Mutaqin et al., 2019a). Third, the marine deposition-barrier spit which covers almost the entire area of Tanjung Luar and creates a lagoon behind the sand bar. Fourth, the subaerial deposition-anthropogenic beach in Labuhan Haji and Surya Wangi is influenced by the natural deposition of fluvial sediments and anthropogenic interferences (Mutaqin, 2020). Fifth, Maiq Anyir is classified as a wave erosion beach because its unconsolidated materials are highly susceptible to wave erosion processes (Mutaqin, 2020). This type of beach also creates a micro-dynamic shoreline that forms rip currents.

Table 1. Classification of coastal typology in the sampling sites, East Lombok

Source: Field survey (2020); Mangga et al., 1994; Mutaqin et al., 2019a; Malawani et al., 2020b; Mutaqin, 2020

\begin{tabular}{|l|l|l|l|l|l|l|}
\hline \multicolumn{1}{|c|}{ Beaches } & \multicolumn{1}{|c|}{ Beach type } & \multicolumn{1}{|c|}{ Materials } & \multicolumn{1}{|c|}{ Sedimentation-erosion } & \multicolumn{1}{|c|}{ Slope } & $\begin{array}{l}\text { Wave } \\
\text { breaker }\end{array}$ & \multicolumn{1}{|c|}{ Typology (genesis) } \\
\hline Kwang Wai & Rocky beach & $\begin{array}{l}\text { Breccia, conglomera- } \\
\text { te, sand }\end{array}$ & $\begin{array}{l}\text { No sedimentation, wave } \\
\text { erosion }\end{array}$ & $\begin{array}{l}\text { Undulating due } \\
\text { to hummock }\end{array}$ & Plunging & Volcanic coast-avalanche \\
\hline Tanjung Luar & Sandy beach & Sand, marsh & $\begin{array}{l}\text { Marine sedimentation- } \\
\text { spit, no erosion }\end{array}$ & Flat & Spilling & $\begin{array}{l}\text { Marine deposition-barrier } \\
\text { spit }\end{array}$ \\
\hline Labuhan Haji & $\begin{array}{l}\text { Sandy-anthropoge- } \\
\text { nic beach }\end{array}$ & $\begin{array}{l}\text { Sandy, coral } \\
\text { fragments }\end{array}$ & $\begin{array}{l}\text { Anthropogenic infill, no } \\
\text { erosion }\end{array}$ & Flat & Spilling & $\begin{array}{l}\text { Subaerial deposition- } \\
\text { anthropogenic }\end{array}$ \\
\hline Surya Wangi & $\begin{array}{l}\text { Sandy-anthropoge - } \\
\text { nic beach }\end{array}$ & Sandy-paving block & $\begin{array}{l}\text { River sedimentation- spit- } \\
\text { no erosion (sea wall) }\end{array}$ & $\begin{array}{l}\text { Slightly gentle } \\
\text { slope }\end{array}$ & Plunging & $\begin{array}{l}\text { Subaerial deposition- } \\
\text { anthropogenic }\end{array}$ \\
\hline Maiq Anyir & Sandy beach & Sand-gravel & $\begin{array}{l}\text { No sedimentation-wave } \\
\text { erosion }\end{array}$ & Gentle slope & Plunging & Wave erosion \\
\hline Gege Korleko & Cliff beach & $\begin{array}{l}\text { Pyroclastic-mix, } \\
\text { ignimbrite }\end{array}$ & $\begin{array}{l}\text { No sedimentation-wave } \\
\text { erosion }\end{array}$ & Cliff & Surging & $\begin{array}{l}\text { Volcanic coast-pyroclastic } \\
\text { surge }\end{array}$ \\
\hline $\begin{array}{l}\text { Bangsal } \\
\text { Korleko }\end{array}$ & $\begin{array}{l}\text { Sandy-rocky-cliff } \\
\text { beach }\end{array}$ & Pyroclastic-mix & $\begin{array}{l}\text { No sedimentation-wave } \\
\text { erosion }\end{array}$ & Gentle-Cliff & Surging & $\begin{array}{l}\text { Volcanic coast-pyroclastic } \\
\text { surge }\end{array}$ \\
\hline
\end{tabular}

\section{Geomorphosite Attributes}

A. Scientific and intrinsic value

The scientific and intrinsic value was assessed from several variables: integrity, rarity, diversity, and scientific knowledge (Table 2). Integrity describes how natural or anthropogenic interferences damage the site and is expressed in 0.5 (disrupted) and 1 (small to no disruptions). Rarity allows one geomorphosite to be assessed for attractiveness similarity with other geomorphosites. The results showed that the samplings sites shared similar attractiveness, except for Kwang Wai and Tanjung Luar (rarity score =1). It has hummocky hills; barrier spit and a mangrove area respectively. These attractive objects are only found at those sites. Diversity refers to the variation of features. All sampling sites had 2-4 features and, thus share similar scores (0.5). The last variable in scientific and intrinsic value is scientific knowledge. Neither scientific studies nor scientific explorations were found in the sampling sites, except in Gege Korleko. This beach geologically lies in deposits of pyroclastic surges and ignimbrites; therefore, the local government considers it as a unique geological site (Figure 4). 


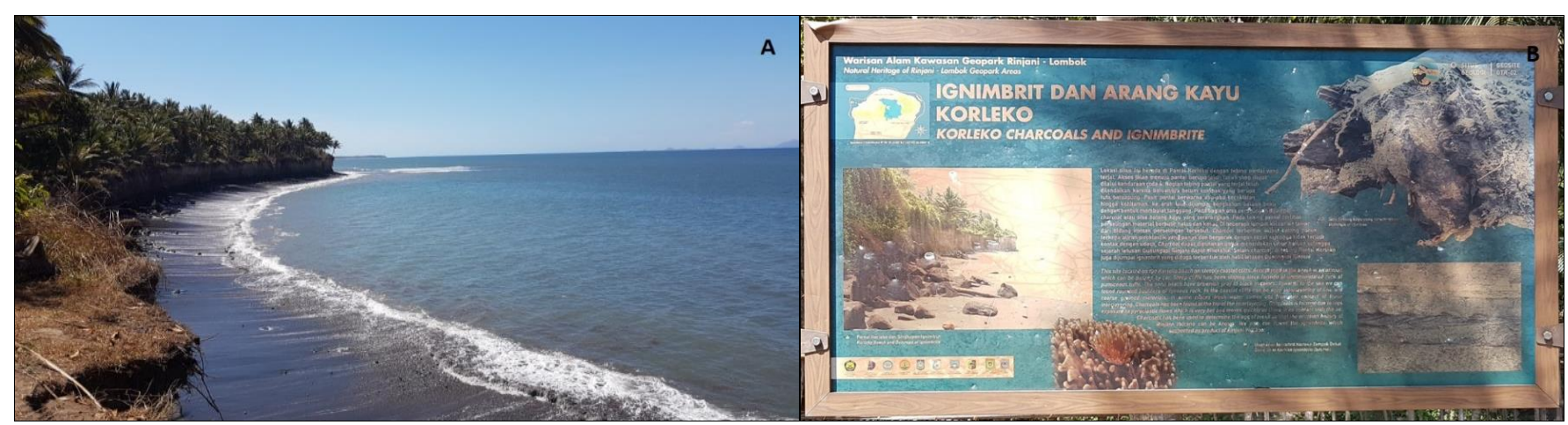

Figure 4. (A) View of Gege Korleko beach and (B) an information board containing the geological

uniqueness of the site. The board explains the processes and age of the ignimbrite formation, as dated from the charcoal presence in this rock back to 1257 CE during the Samalas eruption (Photo source: field survey, 2020)

Table 2. Scientific and intrinsic value assessment of the sampling sites

(A: Kwang Wai; B: Tanjung Luar; C: Labuhan Haji; D: Surya Wangi; E: Maiq Anyir; F: Gege Korleko; G: Bangsal Korleko)

\begin{tabular}{|c|c|c|c|c|c|c|c|}
\hline Variables & $\mathrm{A}$ & $\mathrm{B}$ & $\mathrm{C}$ & $\mathrm{D}$ & $\mathrm{E}$ & $\mathrm{F}$ & $\mathrm{G}$ \\
\hline Integrity & Disturbed (0.5) & $\begin{array}{c}\text { Small-to-no } \\
\text { disruption (1) }\end{array}$ & $\begin{array}{c}\text { Small-to-no } \\
\text { disruption (1) }\end{array}$ & $\begin{array}{c}\text { Small-to-no } \\
\text { disruption (1) }\end{array}$ & Disturbed (0.5) & Disturbed (0.5) & Disturbed (0.5) \\
\hline Rarity & $\begin{array}{c}\text { No shared } \\
\text { similarity (1) }\end{array}$ & $\begin{array}{c}\text { No shared } \\
\text { similarity (1) }\end{array}$ & $\begin{array}{c}\text { Shared } \\
\text { similarity (0.5) }\end{array}$ & $\begin{array}{c}\text { Shared } \\
\text { similarity (0.5) }\end{array}$ & $\begin{array}{c}\text { Shared } \\
\text { similarity (0.5) }\end{array}$ & $\begin{array}{c}\text { Shared similarity } \\
(0.5)\end{array}$ & $\begin{array}{c}\text { Shared } \\
\text { similarity (0.5) }\end{array}$ \\
\hline Diversity & $\begin{array}{c}2-4 \text { features } \\
(0.5)\end{array}$ & $\begin{array}{c}2-4 \text { features } \\
(0.5)\end{array}$ & $\begin{array}{c}2-4 \text { features } \\
(0.5)\end{array}$ & $\begin{array}{c}2-4 \text { features } \\
(0.5)\end{array}$ & $\begin{array}{c}2-4 \text { features } \\
(0.5)\end{array}$ & $2-4$ features $(0.5)$ & $\begin{array}{c}2-4 \text { features } \\
(0.5)\end{array}$ \\
\hline Scientific knowledge & Unknown (0) & Unknown (0) & Unknown (0) & Unknown (0) & Unknown (0) & Scientific paper (0.5) & Unknown (0) \\
\hline
\end{tabular}

Table 3. Education value assessment of the sampling sites

(A: Kwang Wai; B: Tanjung Luar; C: Labuhan Haji; D: Surya Wangi; E: Maiq Anyir; F: Gege Korleko; G: Bangsal Korleko)

\begin{tabular}{|l|l|l|l|l|l|l|l|}
\hline \multicolumn{1}{|c|}{ Variables } & \multicolumn{1}{c|}{ A } & \multicolumn{1}{c|}{ B } & \multicolumn{1}{c|}{ C } & \multicolumn{1}{c|}{ D } & \multicolumn{1}{c|}{ E } & \multicolumn{1}{|c|}{ F } & \multicolumn{1}{|c|}{ G } \\
\hline Representativeness & Medium (0.5) & Medium (0.5) & Low (0) & Low (0) & Low (0) & High (1) & Medium (0.5) \\
\hline Pedagogical use & Low (0) & Medium (0.5) & Medium (0.5) & Low (0) & Low (0) & Medium (0.5) & Low (0) \\
\hline Educational product & No (0) & Info panel (1) & Info panel (1) & No (0) & Info panel (1) & Info panel (1) & No (0) \\
\hline Tour guides & No (0) & No (0) & $\begin{array}{l}\text { Specialized } \\
\text { excursion (0.5) }\end{array}$ & No (0) & $\begin{array}{l}\text { Specialized } \\
\text { excursion (0.5) }\end{array}$ & $\begin{array}{l}\text { Specialized } \\
\text { excursion (0.5) }\end{array}$ & No (0) \\
\hline
\end{tabular}

Table 4. Economic value assessment of the sampling sites

(A: Kwang Wai; B: Tanjung Luar; C: Labuhan Haji; D: Surya Wangi; E: Maiq Anyir; F: Gege Korleko; G: Bangsal Korleko)

\begin{tabular}{|l|l|l|l|l|l|l|l|}
\hline Variables & A & B & C & D & E & F & G \\
\hline Accessibility & Small road (0.5) & Main road (1) & Main road (1) & Main road (1) & Small road $(0.5)$ & Earth road (0) & Earth road (0) \\
\hline Tourism infrastructure & Medium (0.5) & High (1) & High (1) & Medium (0.5) & Medium $(0.5)$ & Low (0) & Low (0) \\
\hline Local products & No (0) & No (0) & No (0) & No (0) & No (0) & No (0) & No $(0)$ \\
\hline
\end{tabular}

Table 5. Conservation value assessment of the sampling sites

(A: Kwang Wai; B: Tanjung Luar; C: Labuhan Haji; D: Surya Wangi; E: Maiq Anyir; F: Gege Korleko; G: Bangsal Korleko)

\begin{tabular}{|l|c|c|c|c|c|c|c|}
\hline \multicolumn{1}{|c|}{ Variables } & $\mathrm{A}$ & $\mathrm{B}$ & $\mathrm{C}$ & $\mathrm{D}$ & $\mathrm{E}$ & $\mathrm{F}$ & $\mathrm{G}$ \\
\hline Threat and risk & Existing (0,5) & Low risk (1) & Low risk (1) & Low risk (1) & Existing (0,5) & Existing (0,5) & Existing (0,5) \\
\hline Potential threat & Low (1) & Low (1) & Low (1) & Low (1) & Low (1) & Low (1) & Low (1) \\
\hline Current status & $\begin{array}{c}\text { No protection } \\
(0,5)\end{array}$ & $\begin{array}{c}\text { No destruction } \\
(1)\end{array}$ & $\begin{array}{c}\text { No destruction } \\
(1)\end{array}$ & $\begin{array}{c}\text { No destruction } \\
(1)\end{array}$ & $\begin{array}{c}\text { Continuing } \\
\text { destruction (0) }\end{array}$ & $\begin{array}{c}\text { Continuing } \\
\text { destruction }(0)\end{array}$ & $\begin{array}{c}\text { Continuing } \\
\text { destruction (0) }\end{array}$ \\
\hline Legislative protection & No (0) & No (0) & No (0) & No (0) & No (0) & No (0) & No (0) \\
\hline
\end{tabular}

Table 6. Added value assessment of the sampling sites

(A: Kwang Wai; B: Tanjung Luar; C: Labuhan Haji; D: Surya Wangi; E: Maiq Anyir; F: Gege Korleko; G: Bangsal Korleko)

\begin{tabular}{|l|c|c|c|c|c|c|c|}
\hline \multicolumn{1}{|c|}{ Variables } & A & B & C & D & E & F & G \\
\hline Cultural significance & No $(0)$ & No $(0)$ & No $(0)$ & No $(0)$ & No $(0)$ & No $(0)$ & No $(0)$ \\
\hline Ecological significance & Yes (1) & Yes $(1)$ & No $(0)$ & No $(0)$ & No $(0)$ & Yes $(1)$ & Potential $(0.5)$ \\
\hline
\end{tabular}

\section{B. Educational value}

In general, the educational value represents the availability of educational products or purposes in a geomorphosite, and in this research, it was determined using four variables: representativeness, pedagogical use, educational product, and tour guides (Table 3). Representativeness refers to the common perspective of the locals or tourists on the physical features of the site. A large proportion of the sampling sites had low (0) and medium scores (0.5), meaning that the physical features' distinct characteristics remain unknown to the locals or tourists. An exception was found in Gege Korleko where the information board helped the locals and tourists to recognize the physical feature in the site. As for pedagogical uses, the interviews revealed that only three sampling sites, i.e., Tanjung Luar, Labuhan Haji, and Gege Korleko, offered excursions for students (0.5). However, even these three 
beaches are rarely used for pedagogical excursions and tours that employ local guides' help. Maiq Anyir had local guides, but it was not designed for pedagogical tours yet. However, these guides were willing to help tourists who needed assistance during a tour. The four sampling sites (Tanjung Luar, Labuhan Haji, Maiq Anyir, and Gege Korleko) had educational products in the form of an information panel displaying general information (1), site plan, warning signs, evacuation routes, and assembly points. As for Gege Korleko, its information boards showed scientific-historical and geological information.

C. Economic value

The economic value describes the practical economic use of a geomorphosite, and in this research, it was a combination of accessibility, tourism infrastructure, and a local product (Table 4). Tanjung Luar, Labuhan Haji, and Surya Wangi could be accessed from the main road-hence, categorized as having high accessibility, while only small roads reached Kwang Wai and Maiq Anyir. Gege Korleko and Bangsal Korleko were accessible by cars, preferably motorcycle, via wide tracking roads ( 4m) (lowest accessibility) and had no basis and supporting tourism infrastructures, e.g. information center, parking lot, and toilet. On the contrary, Labuhan Haji and Tanjung Luar had completely built supporting infrastructures for tourists, and the remaining three beaches only had basic infrastructures. All sampling sites offered no local products or commemorative souvenirs associated with them, although there were markets in the Tanjung Luar and Labuhan Haji areas.

D. Conservation value

Conservation value shows the protection strategies implemented in a geomorphosite (Table 5), including mitigation strategies against hazards. Here, it was determined from four variables: threats and risks, potential threats, current status, and legislative protection. All sampling sites had the same threats, namely earthquakes, and tsunami. In the context of earthquakes and tsunamis, the national disaster risk index (IRBI) (BNPB, 2014), places East Lombok in the red zone. Also, analysis of the current status revealed that severe marine erosion continues to morphologically damage some parts of the island, as apparent in Maiq Anyir, Gege Korleko, and Bangsal Korleko. Except in Surya Wangi, sea walls in other sites are reportedly efficient in protecting such erosion, thus creating low-risk areas. The research found that regulations and other forms of legislative protections relating to marine-coastal protection in all sampling sites were still lacking. Governments need to incorporate riskmitigation planning, land use planning, and tourism development planning into their marine protection actions.

E. Added value

In this research, the added value comprised cultural and ecological significances of a geomorphosite. Because there were no specific cultural events or forms of attractiveness - a crucial element for tourism development, all sampling sites had zero cultural value. In Lombok, Kuta Beach (Central Lombok) is an example of coastal tourism development that positively turns its uniqueness into a cultural event called the Bau Nyale festival (a traditional fishery festival to commemorate the Princess of Mandalika). Also, several sites have important value for their ecological existence. We have identified that recent volcanic environment such as in Gege Korleko is beneficial for their ecological value, especially for scientific purposes. In addition, a mangrove ecosystem growing in Tanjung Luar also increases its ecological significance, and the lagoon creates an economic opportunity as the locals use it for salt ponds.

Table 7. The relation between coastal typology and geomorphosite value assessment

\begin{tabular}{|c|c|c|c|c|c|c|c|}
\hline Geomorphosite attributes & Kwang Wai & Tanjung Luar & Labuhan Haji & Surya Wangi & Maiq Anyir & Gege Korleko & Bangsal Korleko \\
\hline Typology & $\begin{array}{c}\text { Volcanic coast- } \\
\text { avalanche }\end{array}$ & $\begin{array}{c}\text { Marine } \\
\text { deposition- } \\
\text { barrier spit }\end{array}$ & $\begin{array}{c}\text { Subaerial } \\
\text { deposition- } \\
\text { anthropogenic } \\
\end{array}$ & $\begin{array}{c}\text { Subaerial } \\
\text { deposition- } \\
\text { anthropogenic }\end{array}$ & Wave erosion & $\begin{array}{c}\text { Volcanic coast- } \\
\text { pyroclastic } \\
\text { surge }\end{array}$ & $\begin{array}{l}\text { Volcanic coast- } \\
\text { pyroclastic surge }\end{array}$ \\
\hline Scientific and intrinsic value & 2 & 2.5 & 2 & 2 & 1.5 & 2 & 1.5 \\
\hline Educational value & 0.5 & 2 & 2 & 0 & 1.5 & 3 & 0.5 \\
\hline Economic value & 1 & 2 & 2 & 1.5 & 1 & 0 & 0 \\
\hline Conservation value & 2 & 3 & 3 & 3 & 1.5 & 1.5 & 1.5 \\
\hline Added value & 1 & 1 & 0 & 0 & 0 & 1 & 0.5 \\
\hline Total & 6.5 & 10.5 & 9 & 6.5 & 5.5 & 7.5 & 4 \\
\hline
\end{tabular}

\section{Geomorphosite for Ecotourism Development}

Information on coastal typology in the research area is beneficial for characterizing geomorphosite values. Based on the analysis results, several coastal typology characteristics are indeed related to geomorphosite attributes. However, intangible attributes like educational and economic values cannot be directly correlated to coastal typology, e.g., sedimentation-erosion processes attract scholars' attention and, thus, creates scientific and intrinsic values (integrity). Beaches affected by small to no erosion processes tend to have high scores because they have no natural disruption. Knowledge of the sedimentation-erosion rate is also useful for planning coastal management and sustainability, which may include sea walls and/or green-belt vegetation (Yuniastuti, 2016; Wabang et al., 2017). Also, anthropogenic beach protected by coastal infrastructures has a relatively high conservation value score, such as in Labuhan Haji and Surya Wangi. In this assessment, it is apparent that anthropogenic interferences in a coastal area do not always cause negative effects. In Lombok, geomorphosites formed of sub-aerial deposition processes (Labuhan Haji) and marine deposition processes (Tanjung Luar) generally have the highest score (Table 7).

Most importantly, it is highly likely that they have high potentials to be developed as tourist attractions (Marfai et al., 2013). Based on these findings, the research suggests that Tanjung Luar and Labuhan Haji can be immediately developed as coastalmarine ecotourism sites and be the new icon of East Lombok. The mangrove ecosystem in Tanjung Luar also supports this strategy. A best practice example is Bumbang Beach in Central Lombok in which mangrove-based ecotourism was successfully established, and it has created an independent tourist village (Hakim et al., 2018). The current research has identified the vision and mission of Lombok's government for tourism development. With the Lombok motto, "East Lombok tourism: clean, beautiful, respectful, and secure", the government has already planned sustainable tourism. Here, the word secure concerns not only visiting 
tourists but also the natural condition of the geomorphosite. For these reasons, the ecotourism concept is believed to be suitable for East Lombok's tourism development, especially because this region still relies on successful mountain tourism and ecotourism in Rinjani Park and Sembalun. Sadikin et al. (2017) concluded that the ecotourism management of Rinjani Park remain requires immediate improvement, i.e., the addition of appropriate eco-friendly infrastructure. East Lombok's coastal area can adopt this management strategy because most geomorphosites observed in this research have average-to-poor tourist infrastructure and accessibility (economic value). Sembalun ecotourism is also successful in introducing and monetizing the local products (Ariani et al., 2019), and it creates an excellent example for all sampling sites as they currently have no local products to offer (economic value). Another factor that coastal ecotourism development needs to take into account is natural hazards. Hazard and disaster events indeed have substantial impacts on tourism activities (Wahyuningtyas et al., 2019). Based on the national disaster risk index (IRBI) (BNPB, 2014), East Lombok is at high risk of being severely affected by tsunamis. On a detailed scale, cliff beach, such as in Gege Korleko and Bangsal Korleko, tends to be safer than other beach types. Although the most recent tsunami in East Lombok was caused by an underwater earthquake in 1977 (Pradjoko et al., 2015), the hazard still exists (Mutaqin et al., 2019b; Mutaqin et al., 2021). Also, Lombok lies in an earthquake-prone zone, and the 2018 earthquake disturbed tourism development in all regions of Lombok, as well as in East Lombok. After recovery to its normal condition in late 2019, this sector was severely hit by the COVID-19 pandemic and is thereby growing very slow (Fathurrahim, 2020). Lombok has just recently started to revitalize its tourism by implementing public health protocols. However, this strategy does not entirely work for ecotourism because social interaction between tourists and operators (guides) is key to successfully adopting the ecotourism concept. In this case, the pandemic creates a new challenge for ecotourism development in East Lombok, and probably for entire the world.

\section{CONCLUSION}

Geomorphosite assessment is a robust method of analyzing the readiness of a site for ecotourism development, especially when combined with coastal typology identification. Coastal typology has a relation with the physical attribution of geomorphosite, but for intangible attributes, it has no direct relation. In the case of East Lombok, only two coastal geomorphosites have a high score in assessed attributes and have a high potential to lead the ecotourism development. The regional planning in the research area also beneficial for ecotourism development, since it has been concerned with the ecotourism concept. However, it is highly suggested that the potential ecotourism sites start to develop local products as part of their attractiveness. At the same time, the local government needs to take into account the natural hazards because in the research area remains a lack of detailed maps or information to support and realize tourism protection. The pandemic has also influenced the implementation of the ecotourism concept, which has therefore created a new challenge for all those interested in this field.

\section{Acknowledgment}

The authors would like to thank the Ministry of Research, Technology, and Higher Education of the Republic of Indonesia for funding the project on which this article is based under the Leading Basic Research in Higher Education scheme (contract number 1675/UN1/DITLIT/DIT-LIT/PT/2020). Thanks to Riha A. Muhammad for the assistance during field survey.

\section{REFERENCES}

Ariani, D., Zuska, F., Manurung, R., Ismalil, R., \& Munthe, H.M. (2019). Village woman in Sembalun Lawang, ecotourism area, at the foot of Rinjani volcano, east Lombok, Indonesia. Int. Journal of Sci. \& Tech, 8(12), 1152-1160.

Badarab, F., Trihayuningtyas, E., \& dan Suryadana, M.L. (2017). Strategi pengembangan destinasi pariwisata di Kepulauan Togean Provinsi Sulawesi Tengah [Strategy for developing tourism destinations in the Togean Islands, Central Sulawesi Province]. Tourism and Hospitality Essentials (THE) Journal, 7(2), 97-112, (in Indonesian). https://doi.org/10.17509/thej.v7i2.9016

Buckley, R. (2003). Case studies in ecotourism. Cabi Publishing, Cambridge.

Costa, F.L. (2011). Volcanic geomorphosites assessment of the last eruption, on April to May 1995, within the natural park of Fogo Island, Cape Verde. GeoJournal of Tourism and Geosites, 8(2), 167-177.

De Waele, J., Di Gregorio, F., \& Pala, A. (2005). Karst geomorphosites of Monte Albo (north-East Sardinia). Italian Journal of Quaternary Sciences, 18(1), 145-153.

Fathurrahim, F. (2020). Pariwisata Provinsi Nusa Tenggara Barat pada era COVID-19 [Tourism of Nusa Tenggara Barat Province in COVID-19 era]. Media Bina Ilmiah, 15(2), 4057-4062, (in Indonesian).

Hakim, M., Hakim, A., Hakim, L., \& Harahab, N. (2018). Coastal tourism management model toward developing independent tourist village in central Lombok district, Indonesia. Resources, 7, 7-69. https://doi.org/10.3390/resources7040069

Hegde, V.S., Nayak, S.R., Shalini, G., Krishnaprasad, P.A., Girish, K.H., \& Tejaswini, B. (2012). Spit dynamics along the central west coast of India: implications for coastal zone management. Journal of Coastal Research, 28 (2), 505-510. https://doi.org/10.2307/41509948

Hill, J., \& Gale, T. (2009). Ecotourism and Environmental Sustainability: Principles and Practice, Ashgate, Burlington.

Khoiriyah, U., Riyanto I.A., Damayanti, M., Siregar E.M., Marfai M.A., \& Cahyadi, A. (2018). Daya dukung kawasan pantai untuk rekreasi, snorkeling, dan mangrove di Kabupaten Lombok Timur [Supporting capacity of coastal areas for recreation, snorkeling and mangroves in East Lombok Regency]. Seminar Nasional IV Pengelolaan Pesisir dan Daerah Aliran Sungai, Yogyakarta: 24 Oktober 2018, (in Indonesian). https://doi.org/10.31219/osf.io/rs3cx

Kubalíková, L. (2013). Geomorphosite assessment for geotourism purposes. Czech Journal of Tourism, 2(2), 80-104. https://doi.org/10.2478/cjot-2013-0005

Kubalíková, L. (2019). Assessing Geotourism Resources on a Local Level: A Case Study from Southern Moravia (Czech Republic). Resources, 8(3-150). https://doi.org/10.3390/resources8030150

Lavigne, F., Degeai, J.P., Komorowski, J.C., Guillet, S., Robert, V., Lahitte, P., Oppenheimer, C., Stoffel, M., Vidal, C.M., Surono, Pratomo, I., Wassmer, P., Hajdas, I., Hadmoko, D.S., \& de Belizal, E. (2013). Source of the great A.D. 1257 mystery eruption unveiled, Samalas volcano, Rinjani Volcanic Complex, Indonesia. PNAS, 110(42), 16742-16747. https://doi.org/10.1073/pnas.1307520110

Malawani, M.N., Subandriyo, Handayani, T., \& Wicaksono, G.N. (2020a). Comparative morphological differences of stratovolcano in Indonesia. IOP Conference Series: Earth and Environmental Science, 451(012016). https://doi.org/10.1088/1755-1315/451/1/012016

Malawani, M.N., Lavigne, F., Hadmoko, D.S., Marfai, M.A., \& Mutaqin, B.W. (2020b). Hummocky terrain of the Kalibabak debris avalanche deposit, Lombok Island, Indonesia. E3S Web of Conferences, 200(02015). https://doi.org/10.1051/e3sconf/202020002015

Mangga, S.A., Atmawinata, S., Hermanto, Setyogroho, B., \& Amin T.C. (1994). Geological map of the Lombok sheet, West Nusatenggara. Geological Research and Development Centre, Bandung. 
Marfai, M.A., Trihatmoko, E., Ervita, K., \& Purnama, I.S. (2019). Granulometric extraction value to determine waves, currents, and tides characteristic of Tangsi Beach (Pink Beach) East Lombok Regency, Indonesia. IOP Conference Series: Earth and Environmental Science, 256(012030), 1-8. https://doi.org/10.1088/1755-1315/256/1/012030

Marfai, M.A., Ahmada, B., Mutaqin, B.W., Windayati, R. (2020). Dive Resort Mapping and Network Analysis: Water Resources Management in Pemuteran Coastal Area, Bali Island, Indonesia. Geographia Technica. 15(2), 106-116. https://doi.org/10.21163/GT_2020.152.11

Masud, M.M., Aldakhil, A.M., Nassani A.A., \& Azam, M.N. (2017). Community-based ecotourism management for sustainable development of marine protected areas in Malaysia. Ocean \& Coastal Management, 136, 104-112. https://doi.org/10.1016/j.ocecoaman.2016.11.023

Mucivuna, V.C., Reynard, E., \& Garcia, M.D.G.M. (2019). Geomorphosites Assessment Methods: Comparative Analysis and Typology. Geoheritage, 11, 1799-1815. https://doi.org/10.1007/s12371-019-00394-x

Mutaqin, B.W., Lavigne, F. Sudrajat, Y., Handayani, L., Lahitte, P., Virmoux, C., Hiden, Hadmoko, D.S., Komorowski, J., Hananto, N.D., Wassmer, P., Hartono, \& Boillot-Araksinen, K. (2019a). Landscape Evolution on the Eastern Part of Lombok (Indonesia) Related to the 1257 CE Eruption of the Samalas Volcano. Geomorphology, 327, 338-350. https://doi.org/10.1016/j.geomorph.2018.11.010

Mutaqin, B.W., Lavigne, F., Hadmoko, D.S., \& Malawani, M.N. (2019b). Volcanic Eruption-Induced Tsunami in Indonesia: A Review, IOP Conference Series: Earth and Environmental Science. Sci. 256 012023. https://doi.org/10.1088/1755-1315/256/1/012023

Mutaqin, B. (2020). Spatial analysis and geomorphic characteristics of coral reefs on the eastern part of Lombok, Indonesia. Geographia Technica, 15(2), 202-211. https://doi.org/10.21163/GT_2020.152.19

Mutaqin, B.W., Marfai, M.A., Helmi, M., Rindarjono, M.G., Windayati, R., \& Sunarto. (2020). Spatio-temporal Mapping of Ecotourism Activities in Buleleng Conservation Zone: A Methodological Review, IOP Conference Series: Earth and Environmental Science. Sci. 451 012095. https://doi.org/10.1088/1755-1315/451/1/012095

Mutaqin, B.W., Lavigne, F., Wassmer, P., Trautmann, M., Joyontono, P., Gomez, C., Septiangga, B., Komorowski, J.C., Sartohadi, J., \& Hadmoko, D.S. (2021). Evidence of unknown paleo-tsunami events along the Alas Strait, West Sumbawa, Indonesia. Geosciences. 11(2), 46. https://doi.org/10.3390/geosciences 11020046

Nandi (2008). Pariwisata dan pengembangan sumberdaya manusia [Tourism and human resource development]. Jurnal Pendidikan Geografi, 8(1), 33-42. https://doi.org/10.17509/gea.v8i1.1689

Narayan, S., Narayan, P.K., \& Tobing, L. (2021). Has tourism influenced Indonesia's current account?. Economic Analysis and Policy, 69, 225-237. https://doi.org/10.1016/j.eap.2020.12.009

Newsome, D., \& Dowling, R.K. (2006). The scope and nature of geotrourism. In: Dowling, R.K., \& Newsome, D. (Eds.), Geotourism, ButterworthHeinemann, Oxford. https://doi.org/10.1016/B978-0-7506-6215-4.50009-9

Orrù, P., Panizza, V., \& Ulzega, A. (2005). Submerged geomorphosites in the marine protected areas of Sardinia (Italy): assessment and improvement. Il Quaternario, 18(1), 167-174.

Panizza, M. (2001). Geomorphosites: concepts, methods, and examples of geomorphological survey. Chinese Science Bulletin, 46, 4-5. https://doi.org/10.1007/BF03187227

Pattiwael, M. (2018). Konsep pengembangan ekowisata berbasis konservasi di Kampung Malagufuk Kabupaten Sorong [Conservation-based ecotourism development concept in Malagufuk Village, Sorong Regency]. Journal of Dedication to Papua Community, 1(1), 43-54, (in Indonesian). https://doi.org/10.34124/269163

Pereira, L.S., de Carvalho, D.M., \& da Cunha, L.S. (2019). Methodology for the Semi-quantitative Evaluation of Geoheritage Applied to Coastal Geotourism in João Pessoa (Paraíba, Northest Brazil). Geoheritage, 11, 1941-1953. https://doi.org/10.1007/s12371-019-00417-7

Pradjoko, E., Kusuma, T., Setyandito, O., Suroso, A., \& Harianto, B. (2015). The tsunami run-up assessment of 1977 Sumba earthquake in Kuta, Central Lombok, Indonesia. Procedia Earth and Planetary Science, 14, 9-16. https://doi.org/10.1016/j.proeps.2015.07.079

Quesada-Román, A., Zangmo, G.T., \& Pérez-Umaña, D. (2020). Geomorphosite Comparative Analysis in Costa Rica and Cameroon Volcanoes. Geoheritage, 12(90). https://doi.org/10.1007/s12371-020-00515-x

Rayadi, W. (2016). Kajian potensi untuk ekowisata di Pantai Tangsi Kabupaten Lombok Timur Nusa Tenggara Barat dengan menggunakan SWOT analisis [The study of potential for ecotourism in Tangsi Beach, East Lombok Regency, West Nusa Tenggara using SWOT analysis]. Jurnal Green Growth dan Manajemen Lingkungan, 5(2), 10-17, (in Indonesian). https://doi.org/10.21009/jgg.052.02

Reynard, E., \& Panizza, M. (2005). Geomorphosites: definition, assessment and mapping. An introduction. Géomorphologie: relief, processus, environnement, 11(3), 177-180. https://doi.org/10.4000/geomorphologie.337

Sadikin, P.N., Arifim, H.S., Pramudya, B., \& Mulatsih, S. (2017). Carrying capacity to preserve biodiversity on ecotourism in Mount Rinjani National Park, Indonesia. Biodiversitas Journal of Biological Diversity. 18 (3). 978-989. https://doi.org/10.13057/biodiv/d180316

Santos, D.S., Mansur, K.L., Seoane, J.C.S., Mucivuna, V.C., \& Reynard, E. (2020). Methodological Proposal for the Inventory and Assessment of Geomorphosites: An Integrated Approach focused on Territorial Management and Geoconservation. Environmental Management, 66(3), 476-497. https://doi.org/10.1007/s00267-020-01324-2

Shepard, F.P. (1973). Submarine Geology (3rd edition). Harper and Row, New York.

Statistics (2019). Kabupaten Lombok Timur dalam Angka 2019 [East Lombok in Figure 2019], Statistics of East Lombok Regency, East Lombok, Indonesia, (in Indonesian).

Sunarto, Marfaim, M.A., \& Setiawan, M.A. (2014). Geomorfologi dan dinamika pesisir Jepara [Geomorphology and Coastal Dynamics of Jepara], Gadjah Mada University Press, Yogyakarta, Indonesia, (in Indonesian).

Tanaya, D.R., \& Rudiarto, I. (2014). Potensi Pengembangan ekowisata berbasis masyarakat di kawasan Rawa Pening, Kabupaten Semarang [The potential of community-based ecotourism development in the Rawa Pening area, Semarang Regency]. Jurnal Teknik PWK, 3(1), 71-81, (in Indonesian).

Wabang, I.L., Yulianda, F., \& Adisusanto, H. (2017). Kajian karakteristik tipologi pantai untuk pengembangan wisata rekreasi di suka alam perairan Selat Pantar Kabupaten Alor [Study of the characteristics of coastal typology for the development of recreational tourism in the natural waters of the Pantar Strait, Alor Regency]. Albacore, 1(2), 199-209, (in Indonesian). https://doi.org/10.29244/core.1.2.199-209

Wahyuningtyas, N., Tanjung, A., Idris, I., \& Dewi, K. (2019). Disaster mitigation on cultural tourism in Lombok, Indonesia. GeoJournal of Tourism and Geosites, 27(4), 1227-1235. https://doi.org/10.30892/gtg.27409-428

Yuniastuti, E. (2016). Identifikasi tipologi dan dinamika, potensi dan permasalahan, dan strategi pengelolaan wilayah kepesisiran di Wilayah Kepesisiran Demak [Identification of typology and dynamics, potentials and problems, and strategy of coastal area management in Demak Coastal Area]. Jurnal Geografi, 8(1), 31-46, (in Indonesian).

Zacarias, D., \& Loyola, R. (2017). How Ecotourism Affects Human Communities. In: Blumstein D., Geffroy B., Samia D., Bessa E. (Eds). Ecotourism's Promise and Peril. Springer, Cham. https://doi.org/10.1007/978-3-319-58331-0_9

Zhang, W. (2016). SPIT. In: Kennish M.J. (Eds). Encyclopedia of Estuaries. Encyclopedia of Earth Sciences Series. Springer, Dordrecht. https://doi.org/10.1007/978-94-017-8801-4_125

*** BNPB. (2014). Indeks Risiko Bencana Indonesia (IRBI) tahun 20013 [national disaster risk index 2013]. Direktorat Pengurangan Risiko Bencana, BNPB, Jakarta, (in Indonesian).

*** Peraturan Daerah Provinsi Nusa Tenggaa Barat No. 7/2013 tentang Rencana Induk Pembangunan Kepariwisataan Daerah tahun 2013-2028 [Regional Law of West Nusa Tenggara Province No. 7/2013, Regional Tourism Development Master Plan for 2013-2028], (in Indonesian). 